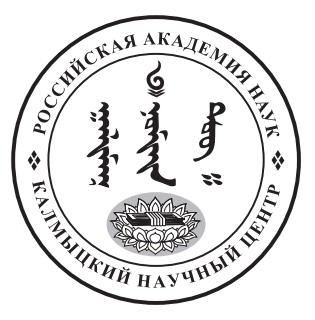

Published in the Russian Federation

Oriental Studies (Previous Name: Bulletin of the Kalmyk Institute

for Humanities of the Russian Academy of Sciences)

Has been issued as a journal since 2008

ISSN: 2619-0990; E-ISSN: 2619-1008

Vol. 14, Is. 1, pp. 33-42, 2021

Journal homepage: https://kigiran.elpub.ru

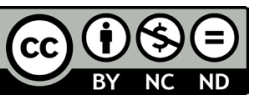

УДК / UDC 94(47)

DOI: $10.22162 / 2619-0990-2021-53-1-33-42$

\title{
К вопросу о раскладке окладных сборов у калмыков в XIX в. (на примере южной части Малодербетовского улуса в 1882 г.)
}

Евгений Николаевич Убушаев ${ }^{1}$, Ольга Николаевна Абеева ${ }^{2}$, Вячеслав Николаевич Авлиев ${ }^{3}$, Нарма Арслангович Каманджаев ${ }^{4}$

${ }^{1}$ Калмыцкий государственный университет им. Б. Б. Городовикова (д. 11, ул. Пушкина, 358000 Элиста, Российская Федерация)

кандидат исторических наук, доцент

iD 0000-0002-5998-9410. E-mail: dip11978@yandex.ru

${ }^{2}$ Калмыцкий государственный университет им. Б. Б. Городовикова (д. 11, ул. Пушкина, 358000 Элиста, Российская Федерация)

кандидат исторических наук, доцент

(iD) 0000-0001-8833-8177. E-mail: olga.abeeva@yandex.ru

${ }^{3}$ Калмыцкий государственный университет им. Б. Б. Городовикова (д. 11, ул. Пушкина, 358000 Элиста, Российская Федерация)

кандидат исторических наук, доцент

iD 0000-0002-1134-0137. E-mail: bartolomeod@yandex.ru

${ }^{4}$ Калмыцкий государственный университет им. Б. Б. Городовикова (д. 11, ул. Пушкина, 358000 Элиста, Российская Федерация)

магистрант

(iD) 0000-0002-2012-0312. E-mail: narmakam@gmail.com

(C) КалмНЦ РАН, 2021

(C) Убушаев Е. Н., Абеева О. Н., Авлиев В. Н., Каманджаев Н. А., 2021

Аннотация. Введение. Статья посвящена изучению раскладки окладных сборов у калмыков в XIX в. с точки зрения аймачных данных. Цели и задачи исследования. Целью настоящей статьи является анализ раскладки окладных сборов у калмыков на аймачном уровне. В соответствии с ней были выдвинуты следующие исследовательские задачи: установить принимавшиеся на аймачном уровне категории сборов, описать механизм аймачной раскладки, провести анализ средних значений окладных сборов по аймакам. Материалы и методы. Источниковой базой исследования послужили сведения о раскладке окладных сборов с калмыков южной части Малодербетовского улуса за 1882 г. Результаты. Раскладка, т. е. финансовый прием, предполагавший распределение общей суммы определенного вида доходов на совокупность объектов 
обложения, стала официально использоваться калмыцкими обществами во второй половине XIX в. Изученные материалы показали то, в каком виде она применялась калмыками на излете обязательных отношений, т. е. в 1880-е гг. Bыводы. Калмыки-простолюдины выплачивали как установленные, так и не установленные Положением 1847 г. категории сборов. В число последних входили «темные» и хозяйственные сборы, а также сбор «на общественные нужды», пополнявший, по нашему мнению, улусный бюджет. Принцип раскладки в это время стал распространяться на всю сумму сборов. Аймачные сходы решали, какие семьи, из тех, что проходили по переписи как «окладные», не будут платить сборы, и делили всю сумму на две части. Одна часть раскладывалась на определенное число голов крупного рогатого скота, а другая выплачивалась каждой истинно окладной кибиткой по установленному сходом тарифу. Между аймаками существовала достаточно ощутимая разница в средних величинах сборов с одной кибитки. Данный показатель зависел, главным образом, от доли тех кибиток, что исключались аймачным сходом из оклада, и удельной величины «неофициальных» сборов в аймаке.

Ключевые слова: калмыки, налоги, раскладка, Калмыцкая степь, Малодербетовский улус, Управление калмыцким народом

Для цитирования: Убушаев Е. Н., Абеева О. Н., Авлиев В. Н., Каманджаев Н. А. К вопросу о раскладке окладных сборов у калмыков в XIX в. (на примере южной части Малодербетовского улуса в 1882 г.) // Oriental Studies. T. 14. № 1. С. 33-42. DOI: 10.22162/2619-0990-2021-53-1-3342

\title{
$1^{\text {th }}$-Century Tax Apportionment for Kalmyk Population Revisited: A Case Study of the Southern Part of Baga Dorbet Ulus, 1882
}

\author{
Evgeny N. Ubushaev ${ }^{\prime}$, Olga N. Abeeva², Vyacheslav N. Avliev ${ }^{3}$, Narma A. Kamandzhaev $^{4}$ \\ ${ }^{1}$ Gorodovikov Kalmyk State University (11, Pushkin St., Elista 358000, Russian Federation) \\ Cand. Sc. (History), Associate Professor \\ (iD)0000-0002-5998-9410. E-mail: dip11978@yandex.ru
}

${ }^{2}$ Gorodovikov Kalmyk State University (11, Pushkin St., Elista 358000, Russian Federation) Cand. Sc. (History), Associate Professor

iD 0000-0001-8833-8177. E-mail: olga.abeeva@yandex.ru

${ }^{3}$ Gorodovikov Kalmyk State University (11, Pushkin St., Elista 358000, Russian Federation) Cand. Sc. (History), Associate Professor

iD 0000-0002-1134-0137.E-mail: bartolomeod@yandex.ru

${ }^{4}$ Gorodovikov Kalmyk State University (11, Pushkin St., Elista 358000, Russian Federation) Graduate Student

(iD) 0000-0002-2012-0312. E-mail: narmakam@gmail.com

(C) KalmSC RAS, 2021

(C) Ubushaev E. N., Abeeva O. N., Avliev V. N., Kamandzhaev N. A., 2021

\begin{abstract}
Introduction. The article analyzes tax apportionment for Kalmyk population in the $19^{\text {th }}$ century through examining aimak-level (Kalm. 'locality, settlement') data. Goals. The study mainly aims at identification of categories of taxes adopted at the aimak level, determination of the tax apportionment mechanism, analysis of average amounts of taxes across different aimaks. Materials. The analyzed documents include reports of 1882 on taxes from southern aimaks of Baga Dorbet (Russ. Maloderbetovsky) Ulus housed by the National Archive of the Kalmykia (Coll. И-15). Results. Apportionment, i.e. a financial method which assumes distribution of the total amount of a certain type of income for a set of taxable objects, was officially adopted by Kalmyks in the second half of
\end{abstract}


the $19^{\text {th }}$ century. The materials show the form in which it was used by the Kalmyks on the eve of the obligatory relationships' cancellation, i.e. in the 1880s. Kalmyk commoners paid both official and non-official taxes - in terms of the Regulations introduced by the Imperial Court for the Kalmyk People's Directorate. The non-official ones included 'dark' and household fees, as well as a 'public needs' fee, which, in our view, went to ulus-level budgets. The period under study witnessed the application of the apportionment principle (guideline) to the entire amount of taxes. Aimak meetings decided which families would not pay taxes to further divide the entire amount into two parts: the first one was apportioned for a certain number of heads of cattle, while the other was paid by each truly dutiable family at a rate set by the meeting. There was a rather tangible difference between aimaks in the average values of taxes per family. This indicator depended mainly on the share of tax-exempt families and the specific value of 'unofficial' taxes in the aimak.

Keywords: Kalmyks, taxes, apportionment, Kalmyk Steppe, Baga Dorbet Ulus, Kalmyk People's Directorate

For citation: Ubushaev E. N., Abeeva O. N., Avliev V. N., Kamandzhaev N. A. $19^{\text {th }}$-Century Tax Apportionment for Kalmyk Population Revisited: A Case Study of the Southern Part of Baga Dorbet Ulus, 1882. Oriental Studies. 2021. Vol. 14(1): 33-42. (In Russ.). DOI: 10.22162/2619-0990-202153-1-33-42

\section{Введение}

Раскладка, т. е. финансовый прием, предполагавший распределение общей суммы определенного вида доходов на совокупность объектов обложения [Истомина 2012: 75], являлась неотьемлемой частью жизни калмыков в XIX в. Без понимания того, каким образом она функционировала на всех административно-территориальных уровнях, мы не можем со всей полнотой ответственности судить о характере социально-экономического развития Калмыцкой степи в этот период.

В целом тематику налогообложения калмыков в XIX в. затрагивает достаточно внушительный круг работ [Батыров 2002; Батыров 2009; Бурчинова 1989; Бурчинова, Гиляшаева 2013; Деев 2008; Команджаев 1999; Команджаев, Горяев 2013; Лиджиева 2015]. При этом следует признать, что специального исследования, посвященного раскладке окладных сборов у калмыков, еще не предпринималось.

Наиболее ценные сведения и рассуждения о раскладке были изложены в статье Л. С. Бурчиновой «Повинности калмыцкого крестьянства в период утверждения капитализма в России (60-е и начало 90-х годов XIX в.)» [Бурчинова 1989]. Однако в ней данное явление анализируется лишь с точки зрения общих данных по Яндыковскому улусу за 1862 и 1868 гг. [Бурчинова 1989:
96, 100]. Следовательно, остается неясным вопрос о раскладке окладных сборов с точки зрения данных по аймакам. Данная статья призвана восполнить этот пробел.

\section{Цели и задачи}

Целью настоящей статьи является анализ раскладки окладных сборов у калмыков на аймачном уровне. В соответствии с ней выдвигаются следующие исследовательские задачи: 1) установить принимавшиеся на аймачном уровне категории сборов; 2) описать механизм аймачной раскладки; 3) провести анализ средних значений окладных сборов по аймакам.

\section{Материалы и методы}

Источниковой базой нашего исследования послужили аймачные сведения о раскладке окладных сборов с калмыков южной части Малодербетовского улуса за 1882 г. 20 июля 1885 г. вышло циркулярное приложение Управления калмыцким народом (УКН) за № 4966, в соответствии с которым всем попечителям и заведующим отдельными частями улусов было поручено не позже 15 сентября 1885 г. доставить в УКН «по прилагаемой форме, сведение о всех окладных денежных сборах с калмыков по аймакам или родам за 1882 г.» [НА РК. Ф. И-15. Оп. 2. Д. 1744. Л. 71].

На основании данного приложения заведующий южной частью Малодербетов- 
ского улуса 10 сентября 1885 г. издал приказ № 1956, в котором поручил аймачным зайсангам, опекунам и хотонным старостам предоставить сведения о раскладке за 1882 г. Всего было представлено 26 сведений, соответствовавших 28 аймакам Южной части Малодербетовского улуса ${ }^{1}$ [НА РК. Ф. И-15. Оп. 2. Д. 1744. Л. 77, 80-107].

Сам факт запроса этих сведений, видимо, объясняется направлением деятельности тогдашнего Главного попечителя калмыцкого народа Н. О. Осипова. По данным Н. П. Мацаковой, Д. В. Амаевой и Л. В. Оконовой, в этот период он собирал различные сведения о быте и хозяйственной жизни калмыков с целью составления проекта по освобождению их от владельческой зависимости и их будущего общественного устройства [Мацакова, Амаева, Оконова 2018: 72]. Об этом косвенно свидетельствует и то, что в марте 1885 г. УКН просило заведующего южной частью Малодербетовского улуса предоставить сведения о годовом бюджете калмыцкой семьи в 4-5 человек [НА РК. Ф. И-15. Оп. 2. Д. 1744. Л. 35].

В рамках настоящего исследования наряду с общенаучной методологией были использованы статистический и типологический методы. При помощи первого были выявлены средние величины окладных сборов по аймакам и установлены основные факторы, повлиявшие на разницу между ними. Второй метод использовался при разбивке категорий сборов на группы и подгруппы.

Раскладка окладных сборов у калмыков в XIX в.

Официальная история раскладки у калмыков начинается 14 октября 1859 г., когда Первый департамент Министерства государственных имуществ (МГИ) своим циркулярным предписанием разрешил выплачивать сборы в пользу Управления и в общественный капитал посредством внутрен-

${ }^{1}$ Аймак зайсанга Арабданова Зёд-Кебютова рода и аймак зайсанга Улюмджиева Ики-Кебютова рода подали общие сведения на двоих. Такая же ситуация и с аймаками зайсангов Санджиева и Му-Нохаева Найнтакинова рода. Также стоит отметить, что сведения по 6 аймакам Южной части Малодербетовского улуса в силу различных причин предоставлены не были [НА РК. Ф. И-15. Оп. 2. Д. 1744. Л. 78, 78об., 79, 79об., 338, 338об., 339]. ней раскладки по числу семейств и на основании размеров поголовья их скота. При этом изначально эта мера реализовывалась только в казенных улусах вследствие отказа населения владельческих улусов выполнять данное предписание [Деев 2008: 284].

Л. С. Бурчинова, опираясь на материалы общественных приговоров, видит причину этого отказа в небольшом размере данных сборов для калмыков владельческих улусов. При этом она отмечает, что впоследствии их выплата все-таки начинает подвергаться раскладке и во владельческих улусах. Но, к сожалению, она не указывает даже примерного времени начала данного процесса [Бурчинова 1989: 95, 98].

В соответствии со статьей № 56 Высочайше утвержденного Положения об управлении калмыцким народом 1847 г. (Положение 1847 г.) калмыки владельческих улусов должны были ежегодно нести следующие денежные повинности: 7 руб. 14 коп. - в пользу владельца улуса (албан), 57 коп. в доход аймачного зайсанга ${ }^{2}, 44$ коп. - на содержание управления и в общественный капитал. Таким образом, общая их сумма равнялась 8 руб. 15 коп. [ПСЗ РИ 1848: 354].

Согласно статье № 61 того же Положения, калмыки обязаны были нести следующие натуральные повинности: 1) снаряжать подводы для чиновников, находящихся в улусах по службе, а также для конвоирования арестантов; 2) поставлять кибитки для жилья чиновникам и казачьим командам там, где не были обустроены стационарные жилища; 3) в случае надобности состоять в улусных пикетах; 4) отправлять ежегодно 200 калмыков для несения кордонной службы по линии Астраханского казачьего войска; 5) заниматься починкой дорог и лесоразведением [ПСЗ РИ 1848: 354].

В 1868 г. кордонная повинность была заменена требованием ежегодно формировать 10 улусных полицейских команд, в каждой из которых должно было насчитываться 10 конных калмыцких воинов [Оконова 2016: 1635].

В исследованных нами документах нашли свое отражения все вышеперечисленные денежные повинности. В сведениях,

${ }^{2}$ Если такового не имелось, население аймака выплачивало по 57 коп. с кибитки в фонд общественного капитала [ПСЗ РИ 1848: 354]. 
поданных аймачными и хотонными начальниками, они были квалифицированы как сборы, «утверждаемые Управлением калмыцким народом», или как «официальные сборы» [НА РК. Ф. И-15. Оп. 2. Д. 1744. Л. 77, 82].

Общая сумма албана в пользу владельца, согласно изученным сведениям, составила 23 333,22 руб. или 50,9 \% от всей годовой совокупности сборов. Сборов в пользу аймачных зайсангов, согласно документам, было внесено 1 863,41 руб. (4,06 \%). В свою очередь сборов на содержание управления было уплачено на 1 437,87 руб. (3,14 \%) [НА РК. Ф. И-15. Оп. 2. Д. 1744. Л. 77, 80-107].

Большинство исследователей склонно во мнении, что реальный размер податей в пользу нойонов и зайсангов зачастую не соответствовал нормативным параметрам в связи с отсутствием контроля за их сбором со стороны имперской администрации. Вносила свои коррективы и частая изменчивость материального положения налогоплательщиков вследствие природных катаклизмов и эпидемий [Батыров 2009: 578; Бурчинова 1989: 106; Деев 2008: 287-288; Команджаев, Горяев 2013: 127].

В отличие от ситуации с владельческой и зайсангской податями УКН производило учет сбора на содержание управления и в общественный капитал. К сожалению, в фондах Национального архива Республики Калмыкия не сохранились отчеты УКН за 1882-1883 гг., ведь именно в них можно было бы найти информацию об уплате данного сбора населением Малодербетовского улуса в 1882 г. В свою очередь отчет УКН за 1884 г. свидетельствует о том, что степное население улуса к началу года недоимок по этому сбору не имело [НА РК. Ф. И-9. ОП. 1. Д. 72. Л. 96об., 97].

В анализируемых сведениях наряду с упомянутыми податями в число «официальных» включался не упоминаемый в Положении 1847 г. сбор «на общественные надобности». Размер его был одинаков во всех аймаках и составлял 2,655 руб. с кибитки. В целом его валовый сбор составил 8678,93 руб., т. е. 18,93 \% от всей окладной суммы [НА РК. Ф. И-15. Оп. 2. Д. 1744. Л. 77, 80-107].

Само наименование подати, а также то обстоятельство, что она собиралась во всех аймаках по равному кибиточному тарифу и в целом составляла относительно большую сумму, указывают на то, что это мог быть единый сбор в пользу улусного бюджета. Согласно И. В. Лиджиевой, местный бюджет формировался, утверждался и исполнялся сходом как институтом местного самоуправления [Лиджиева 2016: 271].

Предположим также, что улусный бюджет мог быть местным аналогом общественного калмыцкого капитала с похожими сферами применения. Тогда средства из него должны были тратиться на строительство домов, общественных зданий, развитие земледелия, помощь пострадавшим в результате несчастных случаев, природных катаклизмов и т. п. [Лиджиева 2015: 18 ].

В группе сборов под названием «неофициальные» или «не утверждаемые УКН» своим размером (6 466,55 руб. или $14,11 \%$ от суммы всех сборов) выделяется сбор на подводную повинность [НА РК. Ф. И-15. Оп. 2. Д. 1744. Л. 77, 80-107]. Отметим, что информация о его выплате есть во всех поданных сведениях. Так как, согласно Л. С. Бурчиновой, все статьи натуральной повинности в период с 1870-х гг. начинают исполняться в денежной форме [Бурчинова 1989: 103], возможно, что средства на исполнение других натуральных повинностей могли выделяться из улусного бюджета, о котором мы писали ранее.

Остальные «неофициальные» сборы считаем нужным разбить на две следующие подгруппы: 1) сборы в пользу должностных лиц (так называемые «темные сборы»), 2) хозяйственные сборы.

Согласно проанализированным сведениям, должностными лицами, для которых устраивались сборы из первой подгруппы, были хотонные старосты, выборные на улусный сход от 20 кибиток, демчеи, старшины и опекуны аймаков.

Единый сбор для хотонных старост и выборных от 20 кибиток собирался во всех 28 аймаках. Его общая сумма равнялась 2373,86 руб. или 5,18 \% от всей совокупности сборов. Остальные сборы из этой подгруппы в силу объективных причин собирались далеко не во всех аймаках. Приведем их вместе: сборы в пользу демчеев 240,6 руб., сборы на содержание аймачных опекунов - 218 руб., сборы в пользу аймачных старшин - 78 руб. [НА РК. Ф. И-15. Оп. 2. Д. 1744. Л. 77, 80-107]. 
В категорию «хозяйственных» мы включили сбор на оплату услуг одного или нескольких частных объездчиков и сбор на обустройство прудов для задержания воды. Данные сборы были направлены на поддержание и совершенствование хозяйственной жизни конкретного аймака. Общая сумма сборов данной категории равнялась 1151 руб. или 2,51\% от всей суммы оклада [НА РК. Ф. И-15. Оп. 2. Д. 1744. Л. 77, 80-107].

Таким образом, сумма всех окладных сборов с 28 аймаков южной части Малодербетовского улуса в 1882 г. равнялась 45839,44 руб. [НА РК. Ф. И-15. Оп. 2. Д. 1744. Л. 77, 80-107].

Анализируя приведенные выше данные, отметим, что калмыцким крестьянам приходилось выплачивать как установленные, так и не установленные Положением 1847 г. категории сборов. В отличие от албана и податей в пользу зайсанга так называемые «неофициальные» сборы вместе со сбором на «общественные надобности» представляются нам по большей части не очередной формой феодальной эксплуатации со стороны калмыцких владельцев, а вынужденными мерами по поддержанию порядка и хозяйственного благополучия в обществе. Таковыми они были потому, что органы местного самоуправления в тот период были практически лишены материальной поддержки со стороны государства [Лиджиева 2015: 18].

Перед рассмотрением механизма аймачной раскладки необходимо прояснить вопрос, связанный с учетом налогооблагаемого населения. С начала $1860-х$ гг. для определения более точного числа калмыков, живших в пределах Калмыцкой степи Астраханской губернии, УКН начинает составлять так называемые посемейные списки, которые становятся основой для раскладки окладных сборов. Нововведением здесь стало то, что теперь при проведении переписи регистрировали каждого члена семьи независимо от пола и возраста [Бурчинова 1989: 92; Деев 2008: 286].

Однако вследствие того, что и простой народ, и привилегированное сословие старались всячески бойкотировать переписи, царская администрация вводит в практику их проведения понятия об «окладной» и «временно неокладной» кибитках. Данные наименования были официально закреплены постановлением Управления калмыцким народом от 26 июня 1869 г., в соответствии с которым окладные сборы не взимались: 1) с одиноких мужчин, живших по одиночке, вне зависимости от их возраста; 2) стариков свыше 60 лет, имевших и не имевших детей; 3) вдов с малолетними детьми; 4) слепых и душевнобольных. Если хозяйство вдовы или старика насчитывало более 100 голов разного скота, то их кибитки считались окладными. Всего, согласно посемейным спискам 1876 г., «временно неокладными» во всей Калмыцкой степи было признано 1761 семейство [Бурчинова 1989: 93].

Данные списки стали основой для раскладки сборов в 1882 г. Неудивительно, что временной лаг в 6 лет привел к той ситуации, что многие кибитки, учтенные в 1876 г. как окладные, были не в состоянии вносить подати. О разнообразных причинах, которые могли повлечь данное состояние, пишут в своем письме от 1885 г. чиновники Малодербетовского улусного управления: «Ежегодные раскладки, как казенные, так и мирские бывают неравны, так что есть в коих числятся умершие лица и не малые бедные кибитки, откочевавшие из пределов улуса на русскую землю; но некоторые из таких лиц не платят повинности, а с иных бедных не взыскивается по неизвестности их последнего места нахождения. И кроме лиц, откочевавших из своего улуса, есть еще и бедные калмыки, которые также бывают не в состоянии уплачивать лежащие на них повинности, за таких несостоятельных калмыков платят по раскладке родового общества богатые их однородцы» (цит. по: [История местного 2017: 173]). Таким образом, причинами, обуславливавшими перекладывание оплаты сборов с одной семьи на другую, были: 1) смерть либо всей семьи, либо кого-то из ее членов; 2) убытие семьи на территорию за пределами юрисдикции УКН; 3) общее обеднение семьи.

Механизм самой раскладки на примере нашей источниковой базы выглядит следующим образом. Каждому аймаку было предписано определенное количество окладных кибиток в соответствии с данными посемейных списков 1876 г. На их основе улусные сходы принимали суммы «официальных» сборов, а также суммы выполнения подводной повинности для каж- 
дого аймака. Затем аймачный сход принимал решение о назначении своих сборов. Из предписанного числа окладных кибиток вычитались те, которые аймачный сход относил к выморочным и бедным. Полученное количество уже по-настоящему или истинно окладных кибиток и выплачивало всю сумму «официальных» и «неофициальных» сборов. Данная сумма затем делилась на две части: сумму, вносившуюся покибиточно, и сумму, платившуюся со скота. Первая из них вносилась каждой истинно окладной кибиткой поровну, а вторая выплачивалась ею же с определенного количества скота по установленному сходом единому тарифу.

Для большей наглядности приведем конкретный пример описанного выше процесса. Общая сумма всех окладных сборов аймака зайсанга Боро-Манджиева рода Оргакин в 1882 г. составила 2836 руб. Из 207 официально окладных кибиток было исключено по бедности и факту смерти 45 кибиток. На полученные 162 кибитки было разложено 1620 руб. (по 10 руб. с каждой), оставшиеся 1216 руб. были разложены на 2436 голов крупного рогатого скота ${ }^{3}$ по тарифу «50 коп. на голову» [НА РК. Ф. И-15. Оп. 2. Д. 1744. Л. 89].

На основе приведенной выше информации можно сделать вывод о том, что в изучаемое время раскладке подвергается уже вся сумма окладных сборов с аймака, а не только сборы в пользу Управления и в общественный капитал, как указывала в своей статье Л. С. Бурчинова [Бурчинова 1989: 98].

Средняя сумма сборов за 1882 г., приходившаяся на одну официально окладную кибитку в южной части Малодербетовского улуса, составила 14,08 руб. Однако после проведения раскладки она, разложенная уже на одну истинно окладную кибитку, равнялась 17,9 руб. ${ }^{4}$ Таким образом, разница между средней окладной суммой после раскладки и до нее составляла 3,82 руб.

Для того чтобы проанализировать средние величины окладных сборов по аймакам, приведем выдержки из сведений о сборах (см. табл. 1).

Таблища 1. Выдержки из сведений об окладных сборах с аймаков южной части Малодербетовского улуса в 1882 г.

[Table 1. Excerpts from tax reports by southern aimaks of Baga Dorbet Ulus. 1882]

\begin{tabular}{|c|c|c|c|c|c|c|}
\hline № & Род, аймак & 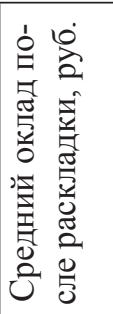 & 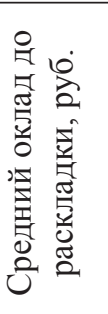 & 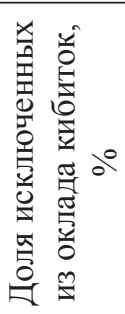 & 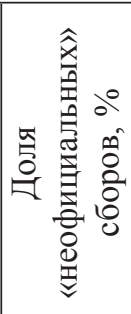 & 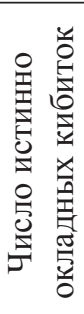 \\
\hline 1 & Ольчанкинов род, аймак зайсанга Лабсаева & 24,38 & 14,41 & 40,91 & 24,99 & 13 \\
\hline 2 & Ульдючинов род, аймак зайсанга Сермекова & 20,63 & 14,63 & 29,07 & 26,18 & 61 \\
\hline 3 & Аймак Богдан-Шебенерова рода & 20,02 & 13,81 & 30,30 & 21,83 & 46 \\
\hline 4 & Аймак Мамадут-Шебенерова рода & 19,64 & 15,28 & 22,22 & 29,27 & 21 \\
\hline 5 & Аймак Абганер-Кебютова рода & 19,38 & 14,26 & 26,47 & 24,25 & 50 \\
\hline
\end{tabular}

${ }^{3}$ Информация о переводном коэффициенте с мелкого рогатого скота на крупный была найдена только в сведениях аймака зайсанга Дондукова Бага-Чоносова рода. В них багачоносовцы пишут, что «в числе упомянутых выше 7643 голов крупного скота вошло баран 6 ш. за одного крупного скота» [НА РК. Ф. И-15. Оп. 2. Д. 1744. Л. 91].
${ }^{4}$ Величина среднего оклада с одной кибитки после раскладки высчитывалась по следующей формуле «X/Y+Z», где X- это количество голов скота, положенного в оклад на аймачном сходе, Y - это число истинно окладных кибиток, $\mathrm{Z}$ - фиксированный сбор с одной кибитки, установленный аймачным сходом. 
Oriental Studies. 2021. Vol. 14. Iss. 1

\begin{tabular}{|c|c|c|c|c|c|c|}
\hline 6 & Бага-Бурулов род, аймак зайсанга Кердеева & 18,97 & 13,70 & 27,78 & 21,09 & 13 \\
\hline 7 & Ульдючинов род, аймак зайсанга Шонтаева & 18,87 & 14,90 & 21,05 & 27,48 & 135 \\
\hline 8 & Ульдючинов род, аймак зайсанга Балзанова & 18,71 & 15,42 & 17,61 & 29,92 & 117 \\
\hline 9 & Ульдючинов род, аймак зайсанга Сумьянова & 18,46 & 14,36 & 22,22 & 24,76 & 140 \\
\hline 10 & Ностанкинов род, аймак зайсанга Менкуева & 17,97 & 13,63 & 24,14 & 20,72 & 44 \\
\hline 11 & Бюдюрмисов род, аймак зайсанга Немгирова & 17,75 & 15,59 & 12,20 & 30,68 & 36 \\
\hline 12 & Шюдючинеров род, аймак зайсанга Корнеева & 17,72 & 13,84 & 21,88 & 21,94 & 50 \\
\hline 13 & $\begin{array}{l}\text { Оргакинов род, аймак зайсанга Боро- } \\
\text { Манджиева }\end{array}$ & 17,51 & 13,71 & 21,74 & 20,32 & 162 \\
\hline 14 & Баганкинов род, аймак зайсанга Джамбаева & 17,45 & 13,35 & 23,53 & 19,92 & 65 \\
\hline 15 & $\begin{array}{l}\text { Джадженкинов род, аймак зайсанга } \\
\text { МуКюкенова }\end{array}$ & 17,25 & 14,85 & 13,95 & 27,22 & 37 \\
\hline 16 & $\begin{array}{l}\text { Джедженкинов род, аймак зайсанга } \\
\text { Монтыкова }\end{array}$ & 17,10 & 14,71 & 13,98 & 26,55 & 80 \\
\hline 17 & $\begin{array}{l}\text { Джарджагакинов род, аймак зайсанга } \\
\text { Джамбаева }\end{array}$ & 17,09 & 12,48 & 27,12 & 13,05 & 43 \\
\hline 18 & $\begin{array}{l}\text { Мандженкинов род, аймак зайсанга } \\
\text { Терменкеева }\end{array}$ & 16,85 & 13,70 & 18,70 & 21,12 & 200 \\
\hline 19 & Хашханеров род, аймак зайсанга Кормыкова & 16,62 & 15,13 & 8,96 & 28,58 & 122 \\
\hline 20 & Бага-Чоносов род, аймак зайсанга Дондукова & 16,55 & 14,65 & 11,50 & 26,28 & 400 \\
\hline 21 & $\begin{array}{l}\text { Джанчиданкинов род, аймак зайсанга } \\
\text { Корнеева }\end{array}$ & 16,47 & 13,39 & 18,70 & 19,30 & 100 \\
\hline 22 & $\begin{array}{l}\text { Найнтакинов род, аймаки зайсангов } \\
\text { Санджиева и Му-Нохаева }\end{array}$ & 16,35 & 13,79 & 15,65 & 23,25 & 124 \\
\hline 23 & Келькетов род, аймак зайсанга Цебекова & 16,29 & 14,29 & 12,30 & 24,34 & 107 \\
\hline 24 & $\begin{array}{l}\text { Бек-Манджекинов род, аймак зайсанга } \\
\text { Нимбуева }\end{array}$ & 16,03 & 12,38 & 23,08 & 12,72 & 60 \\
\hline 25 & Аймак Ики-Чоносова рода & 15,97 & 13,01 & 18,54 & 16,95 & 290 \\
\hline 26 & $\begin{array}{l}\text { Кебютов род, аймаки зайсангов Арабданова и } \\
\text { Улюмджиева }\end{array}$ & 15,39 & 12,74 & 17,20 & 16,10 & 154 \\
\hline
\end{tabular}

Из таблицы 1 следует, что максимальный средний оклад за 1882 г. в Южной части Малодербетовского улуса выплачивался в аймаке зайсанга Лабсаева Ольчанкинова рода - 24,38 руб. Минимальный же показатель наблюдается в аймаках зайсангов Арабданова и Улюмджиева Кебютова рода - 15,39 руб. Таким образом, разница между наибольшей и наименьшей средними окладными суммами среди аймаков составила 8,99 руб.

Ощутимость этой разницы для бюджета калмыцкой семьи того времени можно проследить через цены на основные для тогдашних калмыков продовольственные товары. Так, эквивалентами данной суммы по отдельности были 2 барана (4 руб. за голову), 4 доски чая (цена за одну - 2,3 руб.), 7,5 пу- дов пшеничной муки (цена одного - 1,2 р.) [НА РК. Ф. И-15. Оп. 2. Д. 1744. Л. 44].

Различие в величинах средних окладных сумм можно объяснить влиянием двух факторов. Первый из них - это доля «неофициальных» сборов, прямым образом влияющая на величину среднего оклада до аймачной раскладки. Второй - это доля исключенных аймачным сходом по факту смерти или бедности кибиток. Данный фактор прямо влияет на степень увеличения среднего оклада после раскладки.

Примечательно также то, что на вершине таблицы находятся небольшие аймаки. Судя по всему, в условиях круговой поруки быть причисленным к аймаку в несколько сот человек обычно было выгоднее, чем отбывать повинности в составе небольшого аймака. 


\section{Выводы}

Проведенный анализ сведений об окладных сборах с калмыков южной части Малодербетовского улуса за 1882 г. позволяет нам сделать следующие выводы:

1. Калмыкам-простолюдинам приходилось выплачивать как установленные, так и не установленные Положением 1847 г. категории сборов. В число последних входили «темные» и хозяйственные сборы, а также сбор «на общественные нужды», пополнявший, по нашему мнению, улусный бюджет.

2. Принцип раскладки в это время стал распространяться на всю сумму сборов. Аймачные сходы решали, какие

\section{Источники}

НА РК - Национальный архив Республики Калмыкия.

ПСЗ РИ 1848 - Полное собрание законов Российской империи. Собрание второе. Т. XXII. Отделение первое. СПб.: Тип. II Отделения Собственной Его Императорского Величества канцелярии, 1848.950 с.

\section{Литература}

Батыров 2002 - Батыров В. В. Налоги и повинности калмыков-простолюдинов в конце XVIII и в XIX вв. // Вестник института. Вып. 17. Элиста: КИГИ РАН, 2002. С. 143 149.

Батыров 2009 - Батыров В. В. Социальная структура калмыцкого общества, налоги и повинности // История Калмыкии с древнейших времен до наших дней: в 3-х т. Т. 1. Элиста: ИД «Герел», 2009. С. 572-582.

Бурчинова 1989 - Бурчинова Л. С. Повинности калмыцкого крестьянства в период утверждения капитализма в России (60-е и начало 90-х годов ХІХ в.) // Социально-экономическое и политическое положение крестьянства в дооктябрьский период. Элиста: КНИИИФЭ, 1989. С. 90-113.

Бурчинова, Гиляшаева 2013 - Бурчинова Л. С., Гилямаева М. Н. Обязательные отношения в калмыцких кочевьях накануне реформы 1892 г. // Вестник Калмыцкого института гуманитарных исследований РАН. 2013. № 1. C. $11-16$.

Деев 2008 - Деев С. Ю. Формирование системы налогообложения у калмыков в XIX в. семьи, из тех, что проходили по переписи как «окладные», не будут платить сборы, и делили всю сумму на две части. Одна часть раскладывалась на определенное число голов крупного рогатого скота, а другая выплачивалась каждой истинно окладной кибиткой по установленному сходом тарифу.

3. Между аймаками существовала достаточно ощутимая разница в средних величинах сборов с одной кибитки. Данный показатель зависел, главным образом, от доли тех кибиток, что исключались аймачным сходом из оклада, и удельной величины «неофициальных» сборов в аймаке.

\section{Sources}

Complete Collection of Laws of the Russian Empire. Coll. Two. Vol. XXII. Part 1. St. Petersburg: Second Section of His Imperial Majesty's Own Chancellery, 1848. 950 p. (In Russ.)

National Archive of the Republic of Kalmykia.

// Калмыки в многонациональной России: опыт четырех столетий. Элиста: КалмГУ, 2008. C. 274-290.

Истомина 2012 - Истомина Н. А. Раскладка как прием финансового планирования в губерниях Российской империи // Финансы и кредит. 2012. № 34. С. 74-79.

История местного 2017 - История местного самоуправления Калмыцкой степи в XIX - начале XX вв. Сб. док. и мат-лов / сост. И. В. Лиджиева. Элиста: КалмНЦ РАН, 2017. 240 с.

Команджаев 1999 - Команджаев A. Н. Хозяйство и социальные отношения в Калмыкии в конце XIX - начале XX в.: исторический опыт и современность. Элиста: АПП «Джангар», 1999. 262 c.

Команджаев, Горяев $2013-$ Команджаев А. Н., Горяев М. С. Реформирование налоговой системы Калмыцкой степи во второй половине XIX в. // Теория и практика общественного развития. 2013. № 7. С. 127-131.

Лиджиева 2016 - Лиджиева И. В. Местное самоуправление калмыков в XIX - нач. XX вв. (историко-этнографический аспект). Элиста: КалмНЦ РАН, 2016. 336 с.

Лиджиева 2015 - Лиджиева И. В. Финансо- 
во-хозяйственная деятельность органов местного самоуправления Калмыцкой степи в XIX в. // Вестник Калмыцкого института гуманитарных исследований РАН. 2015. № 1. C. 16-21.

Мацакова, Амаева, Оконова 2018 - Мацакова Н. П., Амаева Д. В., Оконова Л. В. Роль чиновничества в социально-экономическом развитии и управлении Калмыкии в XIX в.

\section{References}

Batyrov V. V. Structure of Kalmyk society, taxes and feudal duties. In: Maksimov K. N., Ochirova N. G. (eds.) History of Kalmykia: From Earliest Times to the Present Days. In 3 vol. Vol. 1. Elista: Gerel, 2009. Pp. 572-582. (In Russ.)

Batyrov V. V. Taxes and feudal duties of Kalmyk commoners, late $18^{\text {th }}-19^{\text {th }}$ centuries. In: Bulletin of the Institute. Vol. 17. Elista: Kalmyk Humanities Research Institute (RAS), 2002. Pp. 143-149. (In Russ.)

Burchinova L. S. Feudal duties of Kalmyk peasants during the establishment of capitalism in Russia, 1860s - 1890s. In: Socioeconomic and Political Conditions Faced by the Peasantry in the Pre-October Era. Elista: Kalmyk Research Institute of History, Philology and Economics, 1989. Pp. 90-113. (In Russ.)

Burchinova L. S., Gilyashaeva M. N. Obligatory relations in Kalmyk nomad territories on the eve of Reform of 1892. Bulletin of the Kalmyk Institute for Humanities of the RAS. 2013. No. 1. Pp. 11-16. (In Russ.)

Deev S. Yu. The shaping of a tax system among Kalmyks, $19^{\text {th }}$ century. In: Kalmyks in Multiethnic Russia. The Four-Centuries-Long Experience. Elista: Kalmyk State University, 2008. Pp. 274-290. (In Russ.)

Istomina N. A. Apportionment as a means of financial planning in governorates of the Russian Empire. Finance \& Credit. 2012. No. 34. Pp. 74-79. (In Russ.)

Komandzhaev A. N. Kalmykia, Late $19^{\text {th }}-$ Early
// Каспийский регион: политика, экономика, культура. 2018. № 4. С. 69-75.

Оконова 2016 - Оконова Л. В. Повинности калмыцкого народа как источник по изучению социально-демографической ситуации Калмыцкой степи Астраханской губернии // Научный журнал Кубанского государственного аграрного университета. 2016. № 123. C. 1629-1638.

20 ${ }^{\text {th }}$ Centuries: Economy and Social Relations in a Historical Perspective. Elista: Dzhangar, 1999. 262 p. (In Russ.)

Komandzhaev A. N., Goryaev M. S. Reformation of the tax system of the Kalmyk Steppe in the late $19^{\text {th }}$ century. Theory and Practice of Social Development. 2013. No. 7. Pp. 127-131. (In Russ.)

Lidzhieva I. V. (comp.) Kalmyk Steppe, $19^{\text {th }}-$ Early $20^{\text {th }}$ Centuries: History of Local SelfGovernment. Collected Documents and Materials. Elista: Kalmyk Scientific Center (RAS), 2017. 240 p. (In Russ.)

Lidzhieva I. V. Financial and economic activity of the institutions of local government in the Kalmyk Steppe in XIX century. Bulletin of the Kalmyk Institute for Humanities of the RAS. 2015. No. 1. Pp. 16-21. (In Russ.)

Lidzhieva I. V. Kalmyk Local Self-Government, $19^{\text {th }}-$ Early 20 $0^{\text {th }}$ Centuries: A Historical Ethnographic Aspect. Elista: Kalmyk Scientific Center (RAS), 2016. 336 p. (In Russ.)

Matsakova N. P., Amaeva D. V., Okonova L. V. The role of bureaucracy in socio-economic development and management of Kalmykia in $19^{\text {th }}$ century. The Caspian Region: Politics, Economics, Culture. 2018. No. 4. Pp. 69-75. (In Russ.)

Okonova L. V. Duties of the Kalmyk people as a source to study the socio-demographic situation in the Kalmyk Steppes of Astrakhan Province. Scientific Journal of Kuban State Agrarian University. 2016. No. 123. Pp. 1629-1638. (In Russ.) 